\title{
Silver Nanoparticle of Acalypha indica Linn. Leaf As Bio-larvicide against Anopheles sp. Larvae
}

\author{
Yos Banne $^{1 * \mathbb{D}}$, Olfie Sahelangi $i^{2} \mathbb{D}$, Steven Soenjono ${ }^{3} \mathbb{D}$, Elisabeth Natalia Barung ${ }^{1}$ D, Selfie Ulaen ${ }^{1}$, Rivolta G. M. Walalangi ${ }^{2}$ \\ (D), Zulfiayu Sapiun ${ }^{4}$ (D) \\ ${ }^{1}$ Department of Pharmacy, Politeknik Kesehatan Kementerian Kesehatan, Manado, Indonesia; ${ }^{2}$ Department of Nutrition, \\ Politeknik Kesehatan Kementerian Kesehatan, Manado, Indonesia; ${ }^{3}$ Department of Environmental Health, Politeknik Kesehatan \\ Kementerian Kesehatan, Manado, Indonesia; ${ }^{4}$ Department of Pharmacy, Politeknik Kesehatan Kementerian Kesehatan, \\ Gorontalo, Indonesia
}

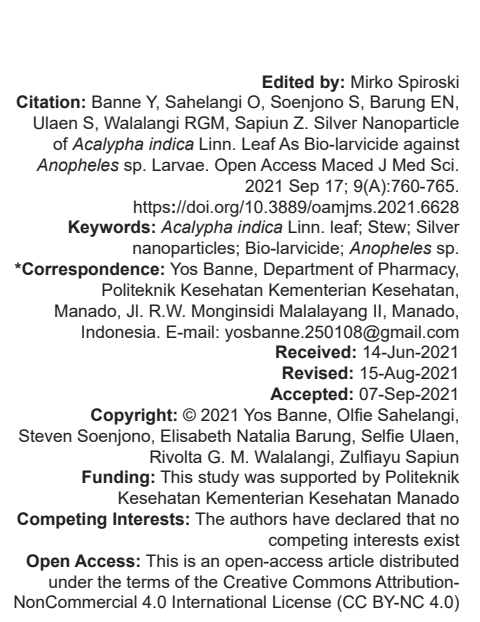

\section{Introduction}

Malaria disease is caused by the Plasmodium parasite, which is spread by female Anopheles mosquitoes. According to the WHO report, globally, there were 229 million cases in 2019 with a mortality rate 10 in 100.000 population at risk [1]. Handling malaria can be done with prevention and treatment. Prevention can be done using insect repellent lotion, removing breeding places and standing water around the house, and killing mosquito larvae by fogging or using larvicides [2]. Chemical substances and natural materials can be used as larvicides. Research on the larvicidal effect has been carried out on several plants for example Acalypha indica Linn. [3], [4], Solanum xanthocarpum, Euphorbia tirucalli, Momordica charantia, Eucalyptus globules, Citrullus colocynthis, A. indica, Annona squamosa, and Solanum nigrum [5].

$A$. indica Linn. is a type of weed wild plants that are often found on the roadside, untreated grass fields even as a nuisance on agricultural land [6].
According to Hayati et al., the components contained in this plant are $\beta$-sitosterol and daucosterol, saponins, tannins, flavonoids, and essential oils [7]. The community has been used this plant as traditional medicine and the results of the researches prove its efficacy, among others, as antidiabetic, antiinflammatory, antioxidant, anti-poison, anticancer, hepatoprotective, antibacterial, wound healing, anthelmintic, repellent, and larvicide [3], [8], [9], [10]. Research conducted by Pratiwi et al. (2015) shows that the ethyl acetate extract of $A$. indica Linn. has a larvicidal effect on Aedes aegypti mosquito larvae with an LC $_{50}$ of 72.444 ppm [10].

Pharmacological effects possessed by natural substances are produced by the content of secondary metabolites. Several methods can be used to find the content of natural ingredients, generally distinguished by the hot method and cold method. The choice of method is based on the physical and chemical properties of the secondary metabolites to be explored. The decoction is one of the simple extraction methods using water as a 
solvent; the material to be extracted must be resistant to heating [12].

Several studies that use natural ingredients try to compare the pharmacological effects produced between plant extracts and plant nanoparticle preparations. The results obtained indicate that an increase in the effect obtained from the preparation of nanoparticles, due to the small particle size of the drug which allows the drug to be absorbed and penetrate quickly into cells and provide the therapeutic effect. Silver nanoparticles are one of the nanoparticle preparations that have been developed. Nano-sized silver metal particles have antimicrobial properties but are environmentally friendly and safe for humans [13], [14]. The green synthesis method uses plant extracts that act as reducing agents which react with metal ions to produce silver nanoparticles. Plant parts can be used in the form of leaves, fruit, or seeds [14]. This study aimed to make the A. indica Linn. leaf stew and silver nanoparticle preparations, and determine the bio-larvicide effect against Anopheles sp. larvae.

\section{Materials and Methods}

\section{Materials}

A. indica Linn. leaves were collected in June from Malalayang district at Manado City. $\mathrm{AgNO}_{3}$ purchased from Merck Company. Polyvinyl alcohol (PVA) purchased from Sigma-Aldrich. Abate purchased from BASF Indonesia. Test animals were Anopheles sp. third instar larvae purchased from Department of Environmental Health, Politeknik Kesehatan Kementerian Kesehatan Manado, Indonesia.

\section{Methods}

\section{Stew and silver nanoparticles preparation}

1. Stew preparation: $A$. indica Linn. leaves taken in the morning and washed with running water, and then the leaves were air-dried. Furthermore, the leaves were coarsely powdered using a grinder. The leaves powder weighed $20 \mathrm{~g}$ and placed in Erlenmeyer containing $200 \mathrm{~mL}$ of distilled water, then simmer for $30 \mathrm{~min}$. Then the solution was cooled to room temperature then filtered with Whatman filter paper no. 1, and the stew was stored in a cold storage cabinet at $4^{\circ} \mathrm{C}$. For the nanoparticle preparation, the stew was diluted with aquadest to obtain a concentration of $0.5,1$, and $5 \%$ [15].

2. Silver nanoparticle preparation: Optimization of the nanoparticles preparation carried out by adding 200, 400, 600, 800, 1000, 1200, 1400, 1600,1800 , and $2000 \mu \mathrm{L}$ of $1 \%$ A. indica Linn. leaf stew to $1 \mathrm{~mL}$ of $1 \mathrm{mM} \mathrm{AgNO}$ solution. Also made preparations using variations in the concentration of $\mathrm{AgNO}_{3} 1-5 \mathrm{mM}$ added with the 0.5 and $5 \% A$. indica Linn. leaf stew. As a stabilizer $0.5 \%$ PVA solution was added for every $2 \mathrm{~mL} \mathrm{AgNO}$. The mixture was allowed to stand in a dark container at cool temperatures for $24 \mathrm{~h}$. The formation of silver nanoparticles was characterized by a change in color of the solution from colorless to slightly turbid brown with wavelengths of $430-480 \mathrm{~nm}$ and particle size of $100 \mathrm{~nm} \geq[15]$. The silver nanoparticle preparation then processed using a freeze dryer.

3. Characterization of silver nanoparticle:

a. UV-Vis spectrophotometer

UV-Vis spectrophotometer was standardized using blank. The extract solution was put in a cuvette and then measured at a wavelength of 350-500 nm [14].

b. Particle size and morphology analysis

The particle size of the extract preparation measured using a Particle Size Analyzer (PSA) [14], [16]. The formulation that has the smallest particle size with the appropriate wavelength was then used in the bio-larvicide test.

\section{Secondary metabolites test}

The test of the secondary metabolites content in the stew was carried out qualitatively using chemical reagents to determine alkaloid, tannin, terpenoid, steroid, flavonoid, and saponin.

\section{Bio-larvicide test}

A total of 10 Anopheles sp. third instar larvae transferred from the container into a vial containing the $A$. indica Linn. stew with a concentration of $0.05 \%, 0.5 \%$, and $5 \%$, control $(+)$ by giving an abate concentration of $0.01 \%$, and control $(-)$ by giving distilled water. Mosquito larvae activity of Anopheles sp. was observed for $24 \mathrm{~h}$. Observation of dead larvae was carried out at the hours 1, 2, $3,4,5$, and 6 . Observation of the flow of life was continued if there were larvae that lived until $24 \mathrm{~h}$ after treatment. Calculation of time begins after the insertion of larvae into glass beakers. Observation of the life cycle, that is, the test larvae were given extracts able to survive for a certain period of time but could not reach the next stage. Larvae are considered dead if there are no more signs of life, for example, do not move anymore even though stimulated by the movement of water and touched with a stick [11].

The data obtained were made in the form of tables and graphs and $\mathrm{LC}_{50}$ values were calculated 
based on Probit analysis.

\section{Results}

\section{Stew and silver nanoparticles preparation}

From 110 samples with varying concentrations of $A$. indica Linn. stew and $\mathrm{AgNO}_{3}$, there were six samples that met the criteria of wavelength $430-480 \mathrm{~nm}$ and particle size on the nanometer scale, as shown in Table 1 and Figure 1.

Table 1: Optimization results of silver nanoparticles of Acalypha indica Linn. leaves

\begin{tabular}{|c|c|c|c|c|c|c|}
\hline \multirow{2}{*}{$\begin{array}{l}\text { Sample } \\
\text { code }\end{array}$} & \multirow[t]{2}{*}{ Mix of } & \multirow[t]{2}{*}{$\lambda(\mathrm{nm})$} & \multicolumn{4}{|c|}{ Particle size $(\mathrm{nm})$} \\
\hline & & & D1 & D2 & D3 & Mean \\
\hline B1 & AlLS $1 \%-\mathrm{AgNO}_{3} 3 \mathrm{mM}$ & $460,449,441$ & 106,7 & 100,6 & 104,9 & 104,1 \\
\hline B2 & AILS $1 \%-\mathrm{AgNO}_{3}^{3} 3 \mathrm{mM}$ & 446 & 88,2 & 96,8 & 108,2 & 97,7 \\
\hline B3 & AILS $1 \%-\mathrm{AgNO}_{3} 3 \mathrm{mM}$ & 451 & 91,8 & 82,5 & 91,8 & 88,7 \\
\hline B4 & AILS $1 \%-\mathrm{AgNO}_{3}^{3} 3 \mathrm{mM}$ & 442 & 100,8 & 101,5 & 99,6 & 100,6 \\
\hline F1 & AlLS $0,5 \%-\mathrm{AgNO}_{3} 5 \mathrm{mM}$ & 431 & 130,0 & 128,1 & 129,6 & 129,2 \\
\hline G3 & AILS $1 \%-\mathrm{AgNO}_{3} 5 \mathrm{mM}$ & 468 & 93,1 & 92,2 & 91,8 & 92,4 \\
\hline
\end{tabular}

Alls: Acalypha indica - inn leaves stew

Based on these results, those who met the criteria as silver nanoparticles $A$. indica Linn. leaves was B3 samples because they have the smallest particle size.

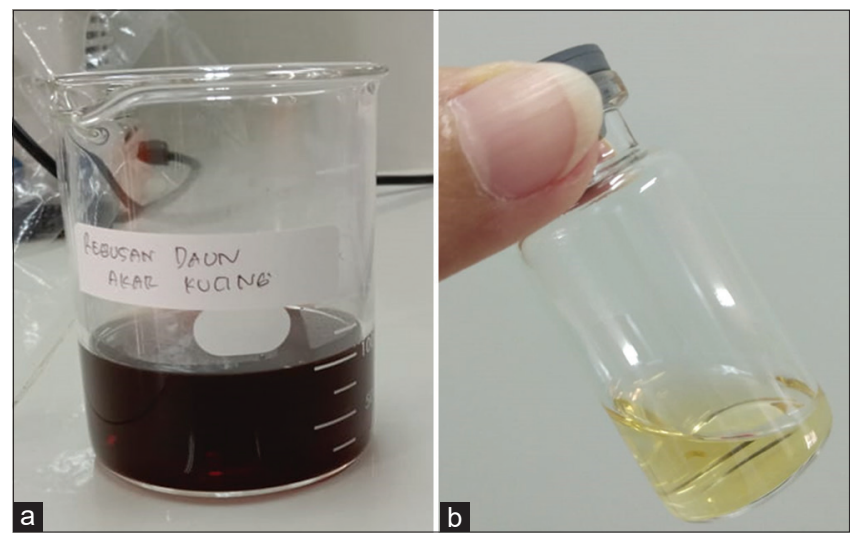

Figure 1: Acalypha indica Linn. leaves stew (a), silver nanoparticles of $A$. indica Linn. leaves stew (b)

\section{Secondary metabolites test}

The test conducted using chemical reagents to determine alkaloid, tannin, terpenoid, steroid, flavonoid, and saponin in the stew. The result showed that all the secondary metabolites tested were contained in the stew (Table 2). The content of these

Table 2: Secondary metabolites in the stew of Acalypha indica Linn. leaves

\begin{tabular}{lc}
\hline Secondary metabolites test & Result \\
\hline Alkaloid & + \\
Saponin & + \\
Tannin & + \\
Flavonoid & + \\
Steroid & + \\
Terpenoid & + \\
\hline +: Contains the compound, -: Non contains the compound. &
\end{tabular}

secondary metabolites produce pharmacological effects.

\section{Bio-larvicide test of stew and silver} nanoparticles of $A$. indica Linn. leaf stew

The results of the bio-larvicides test of $A$. indica Linn. leaf stew and silver nanoparticles of $A$. indica Linn. leaf stew against the larvae of Anopheles sp. Are presented in Table 3.

Table 3: Bio-larvicides effects of stew and silver nanoparticles of Acalypha indica Linn. leaf stew in the larvae of Anopheles sp.

\begin{tabular}{|c|c|c|c|c|}
\hline \multirow[t]{2}{*}{ Sample } & \multicolumn{4}{|c|}{$\begin{array}{l}\text { Mortality percentage of Anopheles sp. mosquito } \\
\text { larvae }\end{array}$} \\
\hline & $\mathrm{N} 1$ & N2 & N3 & Mean \\
\hline Positive control & 100 & 100 & 100 & 100 \\
\hline Negative control & 0 & 0 & 0 & 0 \\
\hline Stew $0,05 \%$ & 60 & 50 & 50 & 53,33 \\
\hline Stew $0,5 \%$ & 80 & 80 & 70 & 73,33 \\
\hline Stew $5 \%$ & 100 & 100 & 100 & 100 \\
\hline Silver Nanoparticle $0.05 \%$ & 90 & 90 & 90 & 90 \\
\hline Silver Nanoparticle $0.5 \%$ & 100 & 100 & 100 & 100 \\
\hline Silver Nanoparticle $5 \%$ & 100 & 100 & 100 & 100 \\
\hline
\end{tabular}

Based on these data, the $\mathrm{LC}_{50}$ value is calculated based on the Probit analysis as follows in Table 4.

Table 4: Probit analysis data for $\mathrm{LC}_{50}$ calculations

\begin{tabular}{lllll}
\hline Sample & Concentration (\%) & Log & \% Mortality & Probit value \\
\hline Stew & 0.05 & -1.30103 & 53.3 & 5.08 \\
Stew & 0.5 & -0.30103 & 73.3 & 5.61 \\
Stew & 5 & 0.69897 & 100 & 8.09 \\
Nanoparticle & 0.05 & -1.30103 & 90 & 6.48 \\
Nanoparticle & 0.5 & -0.30103 & 100 & 8.09 \\
Nanoparticle & 5 & 0.69897 & 100 & 8.09 \\
\hline
\end{tabular}

From the regression equation, the $\mathrm{LC}_{50}$ value for $A$. indica Linn. leaf stew is $0.07273 \%$, if the value is converted to the weight of the $A$. indica Linn. leaf it will be equivalent to 10 fresh leaves $/ 100 \mathrm{~mL}$. While, the $\mathrm{LC}_{50}$ value for nanoparticles of $A$. indica Linn. stew leaf is $0.0003366 \%$.

\section{Discussion}

Samples of $A$. indica Linn. leaves used in dry form. The drying process by air-dried to prevent damage to the content in the leaves due to the sunlight. Stew is one of the simple methods of extracting heat using water as a solvent [11]. The choice of method and solvent is based on the physical and chemical properties of the secondary metabolites to be explored. Polar materials such as flavonoids, saponins, and tannins are extracted with polar solvents such as water and n-butanol [17]. Most flavonoid content is found in the leaves of this plant [18]. The stew was obtained in the form of dark brown liquid with a specific aroma like $A$. indica Linn.

To determine the right formulation of silver nanoparticles, the optimization of the preparations 
was done using various comparisons of several concentrations of stew and $\mathrm{AgNO}_{3}$ solution. The formation of silver nanoparticles is characterized by a brownish yellow color as seen in Figure 1. To ensure, the measurement of the wavelength is compared with the stew of the $A$. indica Linn. leaf. Silver nanoparticles have a wavelength of $430-480 \mathrm{~nm}$, while the stew has a wavelength of $300-380 \mathrm{~nm}$. The particle diameter measurement is done using the PSA. The sample chosen for testing the effects of bio-larvicides was those that had the smallest particle size. The small particle size allows the drug to absorb and penetrate rapidly into cells and provide a therapeutic effect.

The secondary metabolite test conducted using chemical reagents. The result showed that alkaloid, tannin, terpenoid, steroid, flavonoid, and saponin found in the stew. The previous study results showed that this plant contains $\beta$-sitosterol and daucosterol, saponins, tannins, flavonoids, and essential oils [7]. This plant has been used in traditional medicine as antidiabetic, anti-inflammatory, antioxidant, anticancer, hepatoprotective, antibacterial, wound healing, anthelmintic, and larvicide [8], [9]

The bio-larvicide test uses Anopheles sp. third instar larvae and observations are carried out every hour for $6 \mathrm{~h}$ and if there are still mosquitoes that do not die then the observations are carried out for up to $24 \mathrm{~h}$ to observe the life path. The third instar larvae were chosen for the test because the size is larger than the first and the second instar larvae so that the observation becomes easier. Besides that, the third instar larvae are more resistant to current mechanical factors [10]. The results showed that the greater the stew concentration, the greater the percentage of mosquito larvae mortality and the larvae that did not die while the experience period would not grow to the next phase. Komalamisra et al. [19] considered larvicidal products exerting $\mathrm{LC}_{50}<50 \mathrm{mg} / \mathrm{L}$ (active), $50 \mathrm{mg} / \mathrm{L}<\mathrm{LC}_{50}<100 \mathrm{mg} / \mathrm{L}$ (moderately active), $100 \mathrm{mg} / \mathrm{L}<\mathrm{LC}_{50}<750 \mathrm{mg} / \mathrm{L}$ (effective), and LC $\mathrm{C}_{50}>750 \mathrm{mg} / \mathrm{L}$ (inactive). Kiran et al. [20] considered compounds with $\mathrm{LC}_{50}<100 \mathrm{mg} / \mathrm{L}$ as exhibiting a significant larvicidal effect.

Phytochemicals such as alkaloids, phenols, and triterpenoids alone or in combination, contribute to acute toxicity toward various arthropod species [21]. The death of mosquito larvae in this research is presumed due to the secondary metabolites content in $A$. indica Linn. leaves, that is, alkaloid, triterpenoid, flavonoid, tannin, saponin, and steroid. Alkaloid compounds work by disrupting the system nerves (neuromuscular toxic), inhibiting the feeding power of the larva, and acts as a stomach poison. The mechanism of action of the alkaloids, namely by inhibiting the action of the enzyme functioning acetylcholinesterase hydrolyzes acetylcholine. In a state of acetylcholine normally conducts function nerve implants, after which it is immediately experienced hydrolysis with the help of acetylcholinesterase into choline and acetic acid. With the help of this acetylcholinesterase enzyme occurs build-up of acetylcholine to be causes disturbance and damage in the nervous system [22]. Alkaloids also act as an antifeedant and stomach poisoning [23]. Flavonoids act as an insecticide by attacking the nerves in some vital organs of insects, thus arising a weakening of the nerves such as the inhalation resulting in the larvae unable to breathe and finally died. Flavonoids work as a respiratory inhibitor and are considered to disturb the energy metabolism in the mitochondria by inhibiting the conveying system electrons [24]. Triterpenoids are the active components of the limonoid compounds that are toxic used as an insecticide as potential as an antifeedant against insects, growth regulators, and substances toxic to rice lice, larvicides, antimicrobial, insect repellent, and reproductive inhibitor [25]. Steroids have a chemical structure similar to triterpenoids. Steroids are hormone growth that affects the molting of the larvae. Steroids will cause chitin cell walls in the body larvae to thicken; resulting in larval growth will be disturbed and cause death in larvae [26]. Saponins cause a decrease in the activity of digestive enzymes and the absorption of food in insects [27]. In addition, saponins also damage the cuticle membrane of larvae and cause the death of larvae [28]. The tannin compounds contained to act as digestive toxins and interfere with water absorption in larvae so that they can cause death [27], [29].

The $L_{50}$ value shows that nanoparticle preparation has much stronger bio-larvicide effects than the stew. This is possible because of its small size making it easier to penetrate cells, as well as the presence of nanosized silver metal content that has antimicrobial properties but is environmentally friendly and safe for humans [13]. The results obtained in this study indicate the potential for the development of stew and silver nanoparticles of the $A$. indica Linn. leaves to be used as bio-larvicides.

\section{Conclusions}

A. indica Linn. leaves can be extracted with a simple method of stew and the results of the stew can be made into silver nanoparticle preparations. $A$. indica Linn. is a promising larvicidal plant in which the $\mathrm{LC}_{50}$ value of the leaf stew and its silver nanoparticles were $727.3 \mathrm{ppm}$ and $3.366 \mathrm{ppm}$, respectively. It is recommended to conduct similar research on mosquito larvae that cause other diseases such as $A$. aegypti and Culex sp. as well as conducting further research on the stability of silver nanoparticle preparations.

\section{Acknowledgment}

The authors are thankful to the director of Politeknik Kesehatan Kementerian Kesehatan Manado 
for funding support and providing facilities for the research; to the management of the Nanopharmacy Research Center Laboratory of the Department of Pharmacy, Universitas Islam Indonesia for providing facilities for nanoparticle preparation.

\section{Credit Author Statement}

YB: Conceptualization, Methodology, Investigation, Writing-Original draft, Writing- Reviewing and Editing; OS: Visualization, Validation; EB: Formal analysis, Supervision; SS: Resources, Methodology; RW: Resources, Conceptualization; SU: Project administration, Data curation; ZS: Writing- Reviewing and Editing, Data curation.

\section{References}

1. World Health Organization. World Malaria Report 2020, Years of Global Progress and Challenges. Geneva: World Health Organization; 2021. Available from: https://www.who.int. [Last accessed on 2021 Mar 06].

2. Tizifa TA, Kabaghe AN, McCann RS, Berg HV, Vugt MV, Phiri KS. Prevention efforts for malaria. Curr Trop Med Rep. 2018;5(1):41 50. https://doi.org/10.1007/s40475-018-0133-y PMid:29629252

3. Teklani PW, Perera BG. Mosquito repellent and larvicidal activities of Acalypha indica leaf extracts. Int J Pharm Pharmacol. 2017;1(2):107.

4. Karthik S, Suriyaprabha R, Vinoth M, Srither SR, Manivasakan P, Rajendran V, et al. Larvicidal, super hydrophobic and antibacterial properties of herbal nanoparticles from Acalypha indica for biomedical applications. RSC Adv. 2017;7:41763-70. https://doi.org/10.1039/c7ra05697d

5. Gosh A, Chowdhury N, Chandra G. Plant extracts as potential mosquito larvicides. Indian J Med Res. 2012;135(5):581-98. PMid:22771587

6. Pambudi A, Syaefuddin, Noriko N, Swandari R, Azura PR. Identification of flavonoid bioactives from Acalypha indica L. J Al-Azhar Indones Seri Sains Teknol. 2014;2(3):178-87. https:// doi.org/10.36722/sst.v2i3.139

7. Hayati EK, Jannah A, Identification of compounds and antimalarial activity in vivo ethyl acetate extract of the plant Acalypha indica L. Molekul. 2012;7(1):20-32. https://doi. org/10.20884/1.jm.2012.7.1.103

8. Nahrstedt A, Hungeling M, Petereit F. Flavonoids from Acalypha indica. Fitoterapia. 2006;77(6):484-6. https://doi. org/10.1016/j.fitote.2006.04.007

PMid:16828241

9. Duke JA. List of chemicals of Acalypa australis L. In: Phytochemical and Ethnobotanical Databases; 2009. Available from: http://www.sun.arsgrin.gov:8080/npgspub/ xsql/plantdisp.xsql?taxon=406. [Last accessed on 2021 Mar 06].
10. Zahidin NS, Saidin S, Zulkifli RM, Muhamad II, Ya'akob H, Nur H. A review of Acalypha indica L. (Euphorbiaceae) as traditional medicinal plant and its therapeutic potential. J Ethnopharmacol. 2017;207:146-73. https://doi.org/10.1016/j. jep.2017.06.019 PMid:28647509

11. Pratiwi D, Prahastiwi EA, Savitri M. Larvicidal activity test of Acalypha indica Linn herb ethyl acetate extract. against Aedes aegypti mosquito larvae. Farmagazine 2015;2(1):16-23. https:// doi.org/10.20884/1.jm.2012.7.1.103

12. Depkes RI. Direktorat Jenderal Pengawasan Obat dan Makanan. $4^{\text {th }}$ ed. Indonesia: Farmakope Indonesia; 1995 p. $551,713$.

13. Tolaymat T, El Badawy A, Genaidy A, Scheckel K, Luxton T, Suidan M. An evidence-based environmental perspective of manufactured silver nanoparticle in syntheses and applications: A systematic review and critical appraisal of peer-reviewed scientific papers. Sci Total Environ. 2010;408(5):999-1006. https://doi.org/10.1016/j.scitotenv.2009.11.003 PMid:19945151

14. Nalawati AN. Sintesis Nanopartikel Perak (NPAg) Dengan Metode Yang Ramah Lingkungan Dan Kajian Aktivitasnya Dalam Menghambat Pertumbuhan Bakteri Gram Positif dan Bakteri Gram Negatif [Tesis]. Bogor: Institut Pertanian Bogor; 2015. https://doi.org/10.6066/jtip.2017.28.1.27

15. Ahmed S, Ullah S, Ahmad M, Swami BL, Ikram S. Green synthesis of silver nanoparticles using Azadirachta indica aqueous leaf extract. J Radiat Res Appl Sci. 2016;9(1):1-7. https://doi.org/10.1016/j.jras.2015.06.006

16. Abdel-Azis MS, Shahen MS, El-Nekeety A, Abdel-Wahhab MA Antioxidant and antibacterial activity of silver nanoparticles biosynthesized using Chenopodium murale leaf extract. J Saudi Chem Soc. 2014;18:356-63. https://doi.org/10.1016/j. jscs.2013.09.011

17. Harborne JB. Metode Fitokimia. $2^{\text {nd }}$ ed. Indonesia: Penerbit ITB 1987.

18. Kirom HS, Ramadhania ZM. Article Review: Biological Activity of Acalypha indica L. Farmaka. 2015;15(3):162-9.

19. Komalamisra $N$, Trongtokit $Y$, Rongsriyam $Y$, Apiwathnasorn $C$. Screening for larvicidal activity in some Thai plants against four mosquito vector species. Southeast Asian J Trop Med Public Health. 2005;36(6):1412-2. https://doi.org/10.1002/ ptr.1637 PMid:16610643

20. Kiran SR, Bhavani K, Devi PS, Rao BR, Reddy KJ. Composition and larvicidal activity of leaves and stem essential oils of Chloroxylon swietenia DC against Aedes aegypti and Anopheles stephensi. Bioresour Technol. 2006;97(18):2481-4. https://doi. org/10.1016/j.biortech.2005.10.003

PMid:16815011

21. Isman MB. Botanical insecticides: For richer, for poorer. Pest Manag Sci. 2008;64(1):8-11. https://doi.org/10.1002/ps.1470 PMid:18022796

22. Robinson T. Kandungan Organic Tumbuhan Tinggi. $6^{\text {th }}$ ed Indonesia: Penerbit ITB; 1995. p. 191-216.

23. Wardani RS, Mifbakhuddin, Yokorinanti K. Effect of concentration of Tembelekan leaf extract (Lantana camara) on Aedes aegypt larvae death. J Kesehatan Masyarakat Indones. 2010;6(2):30-8. https://doi.org/10.33221/jikm.v9i01.820

24. Ahdiyah I, Purwani KI. The effect of the extract of the leaves of the Mangkokan (Nothopanax scutellarium) as the larvicide of Culex sp. Mosquito. 2015. [cited March 8, 2021]. Available online at http://webcache.googleusercontent.com/ search?q=cache:XnJSEfBeYJ:ejurnal.its.ac.id/index.php/ sains_seni/article/view

25. Li J. Abrief Introduction to Citrus Limonoid. TAMU Colege. 
TAMUK Citrus Centre; 2021. Available from: http://www. ejaefche.wigo.es. [Last accessed on 2021 Mar 06].

26. Diana L. Efektivitas Minyak Atsiri Kulit Jeruk Nipis (Citrus aurantifolia Swingle) Terhadap Mortalitas Larva Aedes aegypti L. Intisar III [Thesis]. Aceh: Universitas Syah Kuala; 2013. https:// doi.org/10.31983/keslingmas.v37i2.3870

27. Pradani FY. Growth Index of Exposed Aedes aegypti L. Larvae in Water Extract of Jengkol (Pithecellobium lobatum) bark.
Aspirator. 2009;1(2):81-5.

28. Gutierrez PM, Aubrey NA, Eugenio BA, Santos MF. Larvicida activity of selected plant extracts against the dengue vector Aedes aegypti mosquito. Int Res J Biol Sci. 2014;3(4):23-32.

29. Mardiana M, Supraptini S, Nunik SA. Datura metel Linnaeus as Botanical Insecticide and Larvicide and Raw Material for Traditional Medicine. Med Penelitian Pengembang Kesehatan. 2009;19(2):1-4. 